\title{
Threats to the presumption of innocence in Irish criminal law: an assessment
}

\author{
By Claire Hamilton* \\ Lecturer in Criminology, Dublin Institute of Technology
}

\begin{abstract}
The existence of four contemporary threats to the presumption of innocence in England and Wales has been posited by Ashworth. The aim of this article is to take stock of the law in the Republic of Ireland impacting upon this cornerstone principle of Irish criminal law. The article explores Ashworth's arguments in more detail and examines the justifications for the presumption of innocence generally and in an Irish context. The precise meaning and ambit of the presumption in Irish law is examined before proceeding to consider the case law and legislation which may have impacted on its scope and practical import for the accused. Several, albeit mixed, conclusions are drawn about the relative health of the presumption in Ireland.
\end{abstract}

Keywords Presumption of innocence; Ireland; Reverse burdens

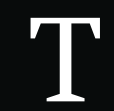

he existence of four contemporary threats to the presumption of innocence in England and Wales has been posited by Ashworth. ${ }^{1}$ In his examination of legislation and case law impacting on the presumption, he concludes 'generally recognised as a fundamental right it may be, but its precise significance for the defendant is so contingent as to raise doubts'. ${ }^{2}$ In light of this rather depressing diagnosis, the aim of this article is to attempt to take stock of the law in the Republic of Ireland impacting upon the presumption of

Email: chamilton@dit.ie.

1 A. Ashworth, 'Four Threats to the Presumption of Innocence' (2006) 10 E\&P 241.

2 Ibid. at 278.

doi:10.1350/ijep.2011.15.3.377

THE INTERNATIONAL JOURNAL OF EVIDENCE \& PROOF (2011) 15 E\&P 181-206 
innocence, arguably one of the most important principles of Irish criminal law. The first part of this article explores Ashworth's arguments in more detail and examines the justifications for the presumption of innocence generally and in an Irish context. An effort will then be made to establish the precise meaning of the presumption in Irish law and its ambit, before proceeding in the final part to consider the case law and legislation which may have impacted on its scope and practical import for the accused. Based on this analysis some conclusions will be drawn about the relative health of the presumption in Ireland.

\section{Whither the 'golden thread'? Confinement; erosion; evasion; side-stepping}

The law is replete with encomia to the presumption of innocence. In the United States, the presumption has been called 'a general principle of our political morality', 'as irresistible as the heavens till overcome, ${ }^{4}$ 'a cornerstone of Anglo-Saxon justice's and a 'bedrock, axiomatic and elementary principle' whose 'enforcement lies at the foundation of the administration of our criminal law'. Every law student is also familiar with the poetic flourish of Lord Sankey in Woolmington $\mathrm{v} \mathrm{DPP}^{7}$ on the burden of proof: 'Throughout the web of the English law one golden thread is always to be seen, that it is the duty of the prosecution to prove the prisoner's guilt'. The Irish superior courts too have acknowledged the principle as a 'fundamental postulate' of the criminal law which is constitutionally protected as part of the right to fair trial. ${ }^{8}$ Indeed, the Supreme Court famously held in People (AG) v O'Callaghan ${ }^{9}$ that the courts owe more than verbal respect to the principle, being 'a very real thing'. Yet, in a legal system which now accommodates preventive detention, the use of silence as evidence against an accused and significantly increased police powers among other developments, the 'reality' of the presumption is increasingly placed in question. There is a danger that as Lacey et al. ${ }^{10}$ have argued:

We take [the presumption of innocence] so much for granted that even the widespread institutional and social practices which sit unhappily with it (the treatment of suspects at police stations; use of

3 W. Twining, Rethinking Evidence: Exploratory Essays (Cambridge University Press: Cambridge, 1990) 208.

4 D. J. B. Thayer, A Preliminary Treatise on Evidence at the Common Law (Little Brown: Boston, 1898) 553.

5 H. J. Abraham, The Judicial Process (Oxford University Press: New York, 1993) 96.

6 Coffin v United States 156 US 432 at 453 (1895).

7 [1935] AC 462.

8 O'Leary v Attorney General [1993] 1 IR 102.

9 [1966] IR 501.

10 N. Lacey, C. Wells and D. Meure, Reconstructing Criminal Law (Weidenfeld and Nicolson: London, 1990) 155. 
custody for 'suspects' refused bail; pressure on people to plead guilty; prejudicial media reporting, to name but a few) do not threaten to displace it, and rarely even call forth critical comment.

In this context Ashworth's comments about the negative effects of recent criminal justice policies on the presumption in England and Wales merit close scrutiny. He identifies threats deriving from four sources, namely, 'confinement, by defining offences so as to reduce the effect of the presumption; erosion, by recognising more exceptions; evasion, by introducing civil law procedures in order to circumvent the rights conferred on accused persons; and side-stepping, by imposing restrictions on the liberty of unconvicted persons that fall only slightly short of depriving them of their liberty'. ${ }^{11}$ The first category appears to envisage circumvention of the presumption through the proliferation of absolute/strict liability offences providing for no-fault criminal liability. Ashworth, however, dismisses arguments that absolute/strict liability offences pose a threat to the principle, preferring to view these offences as offending the principle of 'no criminal liability without fault' pertaining to the substantive rather than the procedural realm of the criminal law. He notes:

There are others who see a great threat to the presumption of innocence arising from the proliferation of criminal liability without fault .... it was argued here that ... it is not necessarily implied by the presumption of innocence that is widely recognised as a human, or constitutional, right. ${ }^{12}$

Taking his point of departure thus, he acknowledges that it is policies falling into the second category, namely reverse-onus provisions, which present the greatest contemporary challenge to the presumption, although mention is also made of possible conflicts arising from the significant incentives to plead guilty through sentence discounts and legislative provisions permitting adverse inferences from pre-trial silence.

The third threat resides in the promotion of legislation which provides for civil orders to control the behaviour of individuals. Two examples cited by Ashworth are anti-social behaviour orders ('ASBOs') which can be made when a court is satisfied that the individual has acted in a manner 'likely to cause harassment, alarm or distress to another' and 'risk of sexual harm orders' which are imposed on persons who have on at least two occasions been involved in sexual activity

11 Ashworth, above n. 1 at 242 (original emphasis).

12 Ashworth, above n. 1 at 257.

THE INTERNATIONAL JOURNAL OF EVIDENCE \& PROOF 
with a child. Both orders can be imposed in the absence of a criminal conviction (although ASBOs can also be imposed after a criminal conviction) and breach of both types of order constitutes a criminal offence punishable by a maximum sentence of five years' imprisonment. The significance of these types of order for the presumption is, as Ashworth argues, the evasion of the protection it normally affords defendants to criminal proceedings. This question was considered some years ago by the House of Lords in $R$ (on the application of McCann) v Manchester Crown Court ${ }^{13}$ who rejected the contention that ASBO proceedings were, 'in reality and in substance', criminal, albeit with the concession that the criminal standard of proof should apply. While this has to some degree mitigated the effect of such provisions, Ashworth voices considerable concern over the panoply of 'hybrid' offences making their way onto the statute book in recent years. Indeed, he describes the government's commitment to the presumption as 'so ambivalent that it will try to avoid its application where possible' ${ }^{14}$

The fourth category of threats to the presumption is related to the third and is formed by the use of civil, preventive orders seeking to control terrorist activity. These 'control orders' were introduced following the decision of the House of Lords in A v Secretary of State for the Home Department ${ }^{15}$ holding that indefinite detention without trial for suspected international terrorists was incompatible with the European Convention on Human Rights. The difference between these orders and those considered in the third category is that the conditions attached to such orders are so restrictive as to border on a deprivation of liberty. Derogating control orders place persons suspected of involvement in 'terrorist-related activity' under effective house arrest and even non-derogating orders may result in significant restrictions on behaviour for a period of up to a year. Evidential requirements fall considerably below proof beyond all reasonable doubt: proof of the requisite conditions on the civil standard of proof is required for a derogating order and a mere reasonable suspicion is sufficient for a non-derogating order. In the absence of any prospect of a criminal trial, the presumption of innocence stricto sensu does not apply, but one may wonder, with Ashworth, whether such 'side-stepping may not impress a Strasbourg Court that looks to the substance of the matter'. ${ }^{16}$

Why should such developments concern us? Reiteration of the justifications for fundamental rights such as the presumption of innocence is particularly important if they are to be viewed not as latter-day white elephants but rather as

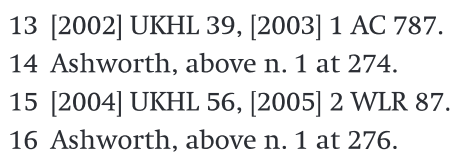


rights which have an intrinsic claim on our attention. Ashworth advances four supporting reasons for the privileged status afforded the presumption, the first (and arguably overarching) of which relates to the fundamental right of an innocent person not to be convicted. Persons placed on trial risk public censure and loss of liberty as well as other serious legal and social consequences. By insisting on a relatively high level of certainty prior to conviction society ensures that the fundamental 'moral harm' (per Dworkin) ${ }^{17}$ or inherent evil of a mistaken conviction is kept to a minimum. Secondly, risk should be allocated to the prosecution on the basis of the 'fragility of fact-finding at trials' and the difficulty in establishing the truth many months or years after the event. A third reason can be located in the respect which the state ought to have for its citizens in a democratic society, bearing in mind the relative imbalance in power and resources between the citizen and the state. A presumption of guilt would seriously undermine respect for the freedom of individuals to go about their business without undue interference from the state. The final justification concerns the standard of proof of beyond all reasonable doubt which Ashworth claims serves to reinforce the previous three values of 'proper respect for the right not to be wrongly convicted, the fragility of fact-finding and disparity of resources'. ${ }^{18}$

Certain points may be added to Ashworth's eloquent defence of the presumption in light of contemporary criticisms of due process protections such as the presumption of innocence. In media and political circles attention is often drawn to the social cost to the presumption and the high standard of proof in terms of the acquittal and release of a number of offenders and the possible danger to public safety. The first concerns what Kennedy ${ }^{19}$ terms the myth of the 'benign state': the view that the enemy is not the essentially benign state but rather the offender in our midst. As she writes: 'We should have learned from history that, in the long-run, abuses by the state are far more dangerous to liberty and democracy than individual criminal conduct, dangerous and disturbing as that is'. ${ }^{20}$ The history lesson is not confined to the bloody feuds of the 17th and 18th centuries. The miscarriages of justice cases in England involving Irish persons suspected of acts of terrorism are well known. Recent cases in Ireland concerning Nora Wall, Pablo McCabe and Dean Lyons serve as salutary reminders of the importance of procedural rights in avoiding an increased violation of individual rights and convictions of the innocent. A related point is that we are all at risk of unjust

17 See further R. M. Dworkin, 'Principle, Policy, Procedure' in C. Tapper (ed.), Crime, Proof and Punishment: Essays in Honour of Sir Rupert Cross (Butterworths: London, 1981) 193.

18 Ibid. at 250.

19 H. Kennedy, Just Law: The Changing Face of Justice and Why It Matters to Us All (Chatto and Windus: London, 2004).

20 Ibid. at 15 .

THE INTERNATIONAL JOURNAL OF EVIDENCE \& PROOF 
conviction. This requires the explosion of another important myth which acts as a barrier to full appreciation of the importance of the presumption of innocence-that of the 'other'. It is often assumed that only 'criminals' will suffer, that 'the innocent have nothing to fear', ${ }^{21}$ yet these rights belong to all citizens and our appreciation of their importance is often stymied by viewing them in this way. Consider a scenario in which a family member has been detained by the police. Ashworth (writing elsewhere) poses the question: 'How would you wish them to be treated? Should it be for the police to decide how long and under what conditions they should be kept, or should they have rights? ${ }^{22}$

Finally, in an Irish context, it is appropriate to consider the broader constitutional framework within which the presumption of innocence is located. While the presumption probably has the strongest association with Article 38.1 of the Constitution, which guarantees that no person shall be tried on a criminal charge except in 'due course of law', it should also be considered in the light of the commitment by the state in the Preamble to promote the common good 'with due observance of Prudence, Justice and Charity so that the dignity and freedom of the individual may be assured'. This approach was clearly endorsed by O'Higgins CJ in State (Healy) v Donoghue $e^{23}$ who invoked the Preamble in support of the courts' view of 'fair procedures': 'In my view the Preamble makes it clear that rights given by the Constitution must be considered in accordance with concepts of prudence, justice and charity'. Considered in this light, particularly the concept of charity, the presumption can be viewed as an embodiment of an essentially positive view of humankind. The connection between this view and the presumption was recognised by the Canadian Supreme Court in $R$ v Oakes. Having outlined traditional explanations of the presumption in terms of the social and personal consequences for the accused, Dickson J continued:

In light of the gravity of these consequences, the presumption of innocence is crucial. It ensures that until the state proves an accused's guilt beyond all reasonable doubt, he or she is innocent. This is essential in a society committed to fairness and social justice. The presumption of innocence confirms our faith in humankind; it

21 It is disappointing to note that even the Irish Supreme Court has adopted this view on occasion. See Heaney v Ireland [1994] 3 IR 593 and commentary of Campbell et al. on this case (L. Campbell, S. Kilcommins and C. O’Sullivan, Criminal Law in Ireland: Cases and Commentary (Clarus Press: Dublin, 2007) 397).

22 A. Ashworth, Human Rights, Serious Crime and Criminal Procedure (Sweet \& Maxwell: London, 2002) 5-6.

23 [1976] IR 325. 
reflects our belief that individuals are decent and law-abiding members of the community until proven otherwise. ${ }^{24}$

Given the importance of the principle in Irish law and the existence of trends in Irish society similar to those described above, ${ }^{25}$ it is timely to engage in an analysis of the tangible effects of the presumption of innocence for an accused person in Ireland. A framework similar to Ashworth's will be adopted for the purposes of assessing the threats to the presumption, although the fourth category of threat is not reflected in Irish law as no statutory mechanism exists for effective house arrest akin to the British provisions on control orders. ${ }^{26}$ Prior to engaging in this analysis, however, it is useful to clarify the scope of the presumption in Ireland as interpreted by the courts as this too impacts on the level of protection afforded accused persons.

\section{Defining the presumption in Ireland}

It is difficult to define the presumption as it is often used to denote different things. As Schwikkard puts it: 'Despite the laudatory rhetoric associated with the presumption of innocence, there is little consensus regarding its contents and scope leading to considerable variation in respect of its normative value. ${ }^{27}$ In its narrowest sense, the presumption can be viewed as merely giving expression to the more prosaic evidential rules that the prosecution bears the burden of proof and that guilt must be proved beyond a reasonable doubt. This view has been espoused by many commentators on the law of evidence. Cross and Tapper, ${ }^{28}$ for example, state that 'when it is said that an accused person is presumed to be innocent, all that is meant is that the prosecution are obliged to prove the case against him beyond reasonable doubt'.

A second view is that the definition of the presumption can also be extended to include the requirement of neutrality for fact-finders. Wigmore ${ }^{29}$ has identified the presumption as incorporating a requirement that the adjudicator ignore all pre-trial indicators of guilt and determine guilt or innocence solely on the

24 R v Oakes (1986) 24 CCC (3d) 321 at 333-4, SCC.

25 See further C. Hamilton, Whittling the Golden Thread: The Presumption of Innocence in Irish Criminal Law (Irish Academic Press: Dublin, 2007).

26 However, it is noteworthy that the High Court held in Brennan v District Court Judge Brennan [2009] IEHC 303 that bail conditions resembling house arrest constituted a breach of Art. 5 of the European Convention on Human Rights.

27 P. J. Schwikkard, 'The Presumption of Innocence: What Is It?' (1998) 11 South African Journal of Criminal Justice 396 at 396.

28 C. Tapper (ed.), Cross and Tapper on Evidence, 10th edn (Butterworths: London, 2003) 135.

29 Wigmore on Evidence, 3rd edn (Little Brown: Boston, 1940) 2511.

THE INTERNATIONAL JOURNAL OF EVIDENCE \& PROOF 
evidence presented in court. This facet of the presumption would appear to be a well-recognised principle of Irish criminal law. Irish juries are told as a matter of course by prosecution counsel at the start of a case that the fact that the Director of Public Prosecutions has seen fit to bring an indictment against the accused is a matter of no moment in relation to the accused's guilt and that they must base their decision solely on the evidence adduced before them in court. It is an aspect of the presumption which may assume an increasing relevance in Ireland, moreover, as Irish society becomes increasingly racially and ethnically diverse. ${ }^{30}$

Finally, in its broadest sense, the presumption may be seen as a means of demanding treatment of a person charged with an offence which is consistent with innocence. This view reinforces a more general principle of liberty within the criminal justice system which extends beyond the trial event itself to the whole criminal justice system and into the realm of police investigation. This approach received the wholehearted endorsement of the Supreme Court in the seminal decision on bail law in People (AG) v O'Callaghan ${ }^{31}$ where Walsh J stated that 'the presumption of innocence until trial is a very real thing and not simply a procedural rule taking effect only at the trial'. More recent Irish decisions also lend support to this view. In People (DPP) v O'Toole ${ }^{32}$ Hardiman J, overturning a conviction in the Court of Criminal Appeal, held that the presumption of innocence should have been explained separately from the burden of proof and not presented as 'merely an alternative way of stating it'. The failure by the trial judge to direct the jury in this way could lead them to regard the presumption as a 'mere technical rule'. The court felt it was necessary to explain to the jury the 'cause and effect' relationship between the presumption and the evidential rules. Hardiman J stated that the 'fundamental importance of the presumption of innocence' which was of 'high constitutional significance' meant that the judge's charge had serious implications for the integrity of the trial.

This decision is clear authority for the principle that the presumption of innocence is a cornerstone principle of Irish criminal law in its own right and not simply a proxy for the evidential rule of proof beyond all reasonable doubt. The Supreme Court found that these two rules are separate and distinct, although conceptually related. Further, it is of note that in a series of sexual abuse cases relating to delay (discussed in greater detail below), the majority of the Supreme Court did not endorse arguments of counsel that the presumption of innocence only applied at trial. The decision can be contrasted with the view taken by the US

302006 census figures show that 10 per cent of the population in Ireland was made up of foreign nationals.

31 [1966] IR 501.

32 [2003] 4 IR 286. 
courts, which have held that the failure to instruct a jury on the presumption is harmless as long as instruction on the reasonable doubt rule has been given. ${ }^{33}$ Such a finding reduces the presumption of innocence to a proxy for the reasonable doubt rule. Significantly, the broader view of the presumption resonates with the jurisprudence of the European Court of Human Rights on Article 6(2) of the European Convention on Human Rights which is now directly enforceable in Irish domestic law. ${ }^{34} \mathrm{~A}$ distinct question from the ambit of the presumption in a procedural sense is the extent to which the presumption may impact on substantive criminal law and this is considered below.

\section{Assessing the buoyancy of the presumption in Irish law}

\section{(a) Confinement: reducing the effect of the presumption}

As noted above, the view that absolute or strict liability offences conflict with the presumption is controversial and one which goes to the very definition of the presumption. In a recent discussion of this area, Tadros ${ }^{35}$ helpfully divides the arguments into three categories. The first may be termed the 'classical school' of thought which has been most forcefully advocated by Roberts ${ }^{36}$ and which sees the presumption as confined to its evidential requirements of proof by the prosecution beyond all reasonable doubt. On this view, reverse-onus provisions will offend the presumption, but the principle has no bearing on the definition of the offence. As we have seen, this is also Ashworth's position although it should be noted that he has engaged in something of an about turn on the matter. ${ }^{37}$ At the other end of the spectrum is the 'moral theory' of the presumption which seeks to protect citizens from being convicted of a criminal offence where their conduct is of the kind that ought not to be criminal. Duff ${ }^{38}$ takes this view in his argument that ' $[t]$ he presumption of innocence ... requires that defendants be convicted only on proof beyond reasonable doubt of what the law legitimately defines as culpable wrongdoing'. Tadros himself, building on an earlier argument made with

33 Taylor v Kentucky 436 US 478 (1978); Arizona v Fulminate 499 US 279 (1991).

34 Salabiaku v France (1988) 13 EHRR 379; CC v United Kingdom [1999] Crim LR 300. The European Convention on Human Rights was incorporated into Irish law via the European Convention on Human Rights Act 2003.

35 V. Tadros, 'Rethinking the Presumption of Innocence' (2007) 1 Criminal Law \& Philosophy 193.

36 P. Roberts, 'Strict Liability and the Presumption of Innocence: An Exposé of Functionalist Assumptions' in A. P. Simester (ed.), Appraising Strict Liability (Oxford University Press: Oxford, 2005) 151-94.

37 A. Ashworth and M. Blake, 'The Presumption of Innocence in English Criminal Law' [1996] Crim LR 306.

38 R. A. Duff, 'Strict Liability, Legal Presumptions, and the Presumption of Innocence' in A. P. Simester (ed.), Appraising Strict Liability (Oxford University Press: Oxford, 2005) 134 (emphasis added). 
Tierney, ${ }^{39}$ claims to steer a middle ground between these two positions, arguing that the presumption mandates treatment of the defendant as innocent of publicly declared wrongdoing. Thus, reverse-onus provisions would offend the principle as well as overly broad legislative provisions which criminalise the activities of some morally innocent individuals where it is too difficult to distinguish them from those who have not. This is because, having regard to the purpose of the offence or the conduct which Parliament intended to criminalise, it has not been shown that the defendant perpetrated a public wrong even by the legislator's own lights of what a public wrong is'. ${ }^{40}$

The debate can be reduced to the relationship between the presumption of mens rea and the presumption of innocence. At common law there is a presumption that mens rea or the 'guilty mind' required to prove the crime is an essential ingredient unless Parliament has indicated a contrary intention either expressly or by necessary implication. The common law presumes that, unless Parliament has indicated otherwise, the appropriate mental element is an unexpressed ingredient of every statutory offence. An expansive reading of the presumption of innocence works in tandem with this presumption in that it requires that the prosecution prove fault as well as the external element of the offence or actus reus.

It is unclear whether the presumption of innocence is viewed by the Irish courts as engaged when considering the constitutionality of offences of strict liability or indeed their compatibility with Article 6(2) of the European Convention on Human Rights. ${ }^{41}$ The case which has come closest to examining the issue is $C C \mathrm{v}$ Ireland, ${ }^{42}$ where the Supreme Court struck down as unconstitutional s. 1 of the Criminal Law (Amendment) Act 1935 which criminalised 'unlawful carnal knowledge' of a girl under 15 . The court did so on the basis that it was a strict liability offence which made no provision for a defence of honest mistake as to the age of the girl. Following the judgment the Oireachtas passed the Criminal Law (Sexual Offences) Act 2006 which provides for a new criminal offence of sexual 'defilement' of a child and also states that it is a defence to this charge for the defendant 'to prove' his honest belief. It is notable that Hardiman J, delivering the judgment

39 V. Tadros and S. Tierney, 'Presumption of Innocence and the Human Rights Act' (2004) 67(3) MLR 402.

40 Tadros, above n. 35 at 203 (original emphasis).

41 The English courts have found no incompatibility with the European Convention on Human Rights. In R v G [2008] UKHL 37, the House of Lords, affirming the earlier decision of the Court of Appeal, held that a strict liability offence which prohibited intercourse with a child under 13 was compatible with the European Convention (incidentally a statutory rape provision very similar to the proposed Irish provision discussed in section (b) below). The House of Lords held that the interpretation and content of domestic substantive law is not engaged by Art. 6 . 42 [2006] 4 IR 1. 
of the Supreme Court, did not rely on the presumption of innocence protected by Article 38.1 of the Constitution but rather the citizen's right to a good name and liberty rights under Article 40.4. However, in the course of his judgment he referred to the concept of mental guilt and the criminalisation of a person who is 'mentally innocent'. The issue is of more than mere academic interest given recent moves in Ireland to amend the Constitution to allow offences of strict/absolute liability to be enacted where they are in some way connected to minors aged under 18. While the government's proposals for a constitutional amendment have been abandoned in favour of legislative reform, ${ }^{43}$ the provisions merit scrutiny given the serious implications which they would have had for the presumption of mens rea and the presumption of innocence in this jurisdiction if adopted. The relevant sections of the abortive Twenty-Eighth Amendment to the Constitution Bill 2007 stated as follows:

Article 42A.5.2. No provision of the Constitution invalidates any law providing for offences of absolute or strict liability committed against or in connection with a child under 18 years of age.

Article 42A.5.3. The provisions of the section of this Article do not in any way limit the powers of the Oireachtas to provide by law for any other offences of absolute or strict liability.

The breadth of these provisions is significant as they were not confined to sexual offences nor indeed to child protection as long as a child is in some way involved in the offence. Article 42A.5.3 would seem to provide for constitutional immunity for absolute/strict liability offences in the criminal law generally. Their successful passage into Irish law would have amounted to a sea change in the law as hitherto (with the obvious exception of an offence of unlawful carnal knowledge) offences of strict liability have been for regulatory type offences with minimal punishments. ${ }^{44}$ It is submitted that the proposed provisions would have represented a de facto if not de jure interference with the presumption of innocence. The practical effect for the defendant is clearly much worse than if he is afforded a defence of mistake as to age and asked to prove it, as is the case under the Sexual Offences Act 2006, although it is not clear from the wording or schema of the Act whether the burden on the accused is a legal or evidential one. To take the contrary view (as,

43 See Joint Oireachtas Committee on the Constitutional Amendment on Children, Second Interim Report on the Twenty-Eighth Amendment to the Constitution Bill 2007 (Stationery Office: Dublin, May 2009).

44 One major exception is the statutory offence of riot created by the Criminal Justice (Public Order) Act 1994 which contains no mens rea requirement and which attracts a penalty of up to 10 years' imprisonment. See Hamilton, above n. 25.

THE INTERNATIONAL JOURNAL OF EVIDENCE \& PROOF 
one would imagine, classical theorists would do) is to elevate form over substance and to encourage the Oireachtas to bypass essential protections by rewriting offences in terms of absolute or strict liability. It is illogical to contend that there is a breach of the presumption when the defendant is provided with a means of proving his innocence and that this is subsequently remedied when he is denied this opportunity. As Tadros writes:

One difficulty with the classical theory is that it implausibly suggests that an offence with a reverse burden defence interferes with the presumption of innocence where the very same offence but with no defence does not. The creation of a reverse burden defence in respect of an offence, which would seem favourable to defendants, thus appears to interfere with their human rights. How can the human rights of the defendant be breached to a greater degree through such an (albeit incomplete) improvement in his circumstances? $?^{45}$

The biggest problem with this approach is that a substantive conception of the presumption appears to legitimise a form of judicial review of the substantive criminal law which permits the judiciary, rather than the legislature, to determine the elements of criminal law offences. In England this presents an obvious difficulty given the principle of parliamentary supremacy. In Ireland, as the CC case itself illustrates, the courts are frequently invited to scrutinise criminal law legislation as part of the process of constitutional judicial review. Despite this, it is by no means clear that the Irish superior courts would wish to become mired in 'moral and political assessment of the legitimacy of substantive criminal law' in the name of the presumption of innocence. ${ }^{46}$ The uncertainty created by an approach which 'requires that defendants be convicted only on proof beyond reasonable doubt of what the law legitimately defines as culpable wrongdoing ${ }^{47}$ is another important consideration. This is where the argument advanced by Tadros assumes particular importance. It would appear relatively uncontroversial that the Oireachtas, in seeking to bring forward this constitutional amendment, was aiming to criminalise those who intentionally have intercourse with young people under the age of 17 or 'would-be sexual predators'. Thus, it is precisely the type of legislation envisaged by Tadros where the legislature criminalises a broader range of activities than those it actually intends to target owing to the evidential difficulties in distinguishing between the two forms of behaviour. In this case, it has been stated on many occasions that the difficulty

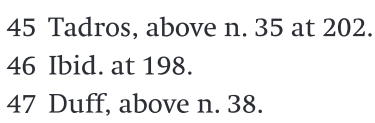


in distinguishing between individuals with and without an honest belief as to age arises from the fact that it would expose young people to "the trauma of crossexamination about their age and appearance' ${ }^{48}$ It is therefore possible, without adopting a fully blown 'moral theory' of the presumption, to advance the argument that the failed amendment can be viewed as an unrealised attack on the presumption in Ireland. This is because it aimed to criminalise those who were morally innocent by the Oireachtas's own lights.

On a more positive note, however, it is salutary to observe that the submissions made to the Joint Oireachtas Committee on the Constitutional Amendment which appeared to influence it in its decision not to proceed with constitutional reform placed great emphasis on the injustice of punishing someone who was morally innocent or blameless. As Dr Gerard Hogan SC wrote: 'if one accepts the contrary argument to that of the Supreme Court, one might as well, for example, equally accept the constitutionality of a statutory offence which provided that every motorist who is involved in a car accident causing death is, by reason of this fact alone, automatically guilty of manslaughter' ${ }^{49}$ Such comments, and the ultimate recommendation arrived at by the Committee, bode well for the influence of the presumption in this jurisdiction, despite the Committee's call for legislation to place the legal burden of proving mistake definitively on an accused charged with sexual defilement.

Other legal practices and reforms which Ashworth viewed as potentially conflicting with the presumption include the guilty plea discount and certain provisions curtailing the accused's right to silence. Taking the former practice first, it is interesting to note that the Irish discount is roughly in line with estimations of the amount of the discount in England and other common law jurisdictions. While received wisdom places it at approximately a third of the sentence, this figure may also be adjusted to take into account the stage at which the plea of guilty was entered. Section 29 of the Criminal Justice Act 1999 provides that the sentencing court, if it considers it appropriate to do so, shall take account of the stage at which the person indicated an intention to plead guilty and the circumstances in which this indication was given. In reality, it is also likely that the discount is applied to varying degrees by different judges in the different courts. Concerning the compatibility of the presumption with the discount, the

48 See, e.g., Office of the Minister for Children, Briefing Note on Proposed Amendment to the Constitution (Stationery Office: Dublin, 2007) 4.

49 Joint Oireachtas Committee on the Constitutional Amendment on Children, Second Interim Report, above n. 43 at 36.

THE INTERNATIONAL JOURNAL OF EVIDENCE \& PROOF 
courts in Ireland have again adopted a position similar to those in other jurisdictions by arguing that the defendant who insists upon a trial is not being punished more than his counterpart but rather his counterpart is being punished less on account of his guilty plea. ${ }^{50}$ Yet, the practical effect of the discount system operated in England, Ireland and other common law countries is that the defendant is punished for his or her decision to put the prosecution to proof and this presents a challenge to our ostensible commitment to the presumption of innocence and adversarial justice generally. Unsurprisingly, few defendants who are, unlike judges, confronted with the reality of the situation have difficulty in arriving at this conclusion. From their interviews with English defendants who pleaded guilty, Baldwin and McConville ${ }^{51}$ found that virtually all defendants viewed this type of reasoning as 'meaningless' and viewed the discount system, regardless of the legal window dressing, as a penalty imposed on those who unsuccessfully contest their case.

Ashworth makes reference to Strasbourg case law where a substantial incentive to plead guilty has been found to breach the presumption. ${ }^{52}$ In Ireland, the potential for improper inducement is particularly marked in certain types of cases. The introduction in 1999 of a mandatory minimum sentence of 10 years' imprisonment in respect of persons charged with possession of drugs valued at over $€ 13,000^{53}$ has placed considerable pressure on such defendants to plead guilty. This is on account of the fact that judges have interpreted the legislation in such a way as to disapply the mandatory minimum where a defendant enters an early plea of guilty or provides material assistance to the Gardaí. In this situation, a typical sentence would probably be in the range of six to seven years. This is problematic as the greater the differential between the sentence which would be received after trial and the sentence received on a plea, the greater the coercive power of the discount. The encouragement of a greater number of guilty pleas was one of the primary motivations behind the enactment of the legislation. However, these risks act as a powerful disincentive to defendants with a reasonable chance of acquittal to contest their case. A recent report commissioned by the

50 In People (DPP) v Gillane, unreported, 21 December 1998, CCA, Lynch J noted: 'Now the first thing to be remembered about this case, as was the Applicant's right, he fought the matter tooth and nail. That is his perfect right. It doesn't add one day to the appropriate sentence, but it does mean that he is not entitled to the discount which is now given virtually as a matter of course ... [when there is a guilty plea].'

51 J. Baldwin and M. McConville, 'The Influence of the Sentencing Discount in Inducing Guilty Pleas' in J. Baldwin and A. Bottomley (eds), Criminal Justice: Selected Readings (Martin Robertson: Oxford, 1978).

52 Ashworth, above n. 1 at 256. He cites Deweer v Belgium (1980) 2 EHRR 439.

53 Misuse of Drugs Act 1977, s. 15A, as inserted by the Criminal Justice Act 1999, s. 4. 
Department of Justice ${ }^{54}$ on the criteria applied by the courts in sentencing under these provisions has noted that in all but one of the 55 cases studied the accused pleaded guilty, a statistic which suggests a much higher rate of guilty pleas than for indictable offences generally. It continues:

The consequences of unsuccessfully testing the prosecution case in a s.15A charge are so severe, it would seem that one of the practical effects of the section has been to discourage the vast majority of accused persons from proceeding to trial unless the case against them appears to be obviously flawed. ${ }^{55}$

Although there is a clear implication in the report that the legislation has had a positive effect on busy court lists, the darker side of a system which produces a constant stream of guilty pleas is that the prosecution case is never tested and the Gardaí and prosecution are provided with little incentive to build a thorough, independent case. The function of the adversarial system of justice is, after all, to prove guilt in a public forum beyond all reasonable doubt. The borderline case where the accused forgoes trial to avail of the discount may be exactly the case where justice is best served through the public proof of guilt.

Some comment must also be reserved for recent legislative developments impacting on the right to silence. While the relationship between this right and the presumption is a contested one in the academic literature, ${ }^{56}$ it has been recognised by Ashworth and others ${ }^{57}$ that, in a practical sense, inference drawing provisions may affect the 'principled asymmetry' between the state and the accused. Ashworth argues that this balance is particularly affected at the pre-trial stage when the power differential between the state and accused may be at its greatest and the state has not yet made out a case to answer. Applying his

54 P. McEvoy BL, 'Research for the Department of Justice on the criteria applied by the courts in sentencing under s.15A of the Misuse of Drugs Act 1977 (as amended)', 15 February 2005, available at <http://www.inis.gov.ie/en/JELR/Pages/Publications_courts_policy_and_legal_services? OpenDocument\&start=11>, accessed 2 May 2011.

55 Ibid. at 11.

56 The argument taken by those who do not see a connection between the two rights is that an accused may still enjoy the benefit of reasonable doubt at trial as the drawing of adverse inferences relates only to the means by which evidence is gathered by the state. This is the position which has been taken by the Irish Supreme Court in Rock v Ireland [1997] 3 IR 484, [1998] 2 ILRM 35 and is also one which is argued for by various legal commentators such as I. Dennis, 'Instrumental Protection, Human Right or Functional Necessity? Reassessing the Privilege against Self-incrimination' (1995) 54(2) CLJ 342 and P. Roberts and A. Zuckerman, Criminal Evidence (Oxford University Press: Oxford, 2002).

57 See, e.g., J. E. Stannard, 'A Presumption and Four Burdens' (1994) 51(4) NILQ 560 and S. Easton, The Case for the Right to Silence, 2nd edn (Ashgate: Aldershot, 1998). 
observations to newly enacted Irish provisions in the Criminal Justice Act 2007 and the Criminal Justice (Amendment) Act 2009 strong concerns must be voiced about their impact on the presumption. Section 30 of the Criminal Justice Act 2007 inserts a new s. 19A into the Criminal Justice Act 1984 allowing a court to draw an adverse inference from an accused person's failure during questioning to mention a fact which he later relies on in defence. A number of safeguards exist for a suspect in these circumstances, including the right to be cautioned as to the effect of the provisions, to have the interview electronically recorded and (perhaps most significantly) the right to consult with a solicitor immediately prior to answering the relevant questions. Yet, to recall Ashworth's comments, it is a matter of some anxiety that inferences may be drawn in a situation where the suspect and his solicitor are not fully appraised of the state case against him and where the solicitor is not present during interviews.

In Ireland, a suspect has a constitutional right to reasonable access to a legal adviser and to consult with him or her privately, but unlike detainees in England this does not extend to a solicitor being present during interview. ${ }^{58}$ While at a doctrinal level the legal burden of proof is unaffected, this important power differential raises questions about to what extent adverse inference provisions compromise (at least at the level of "tangible consequences ${ }^{\text {,59 }}$ ) evidential guarantees of prosecutorial proof beyond all reasonable doubt. Given that the accused in Ireland enjoys a constitutionally protected presumption of innocence mandating state proof of every aspect of the offence, it may be justifiably argued that the state is using the suspect to do its job for it. New provisions aimed at those involved in organised crime are even broader in their import. Section 9 of the 2009 Act inserts a new s. 72A into the Criminal Justice Act 2006 so that adverse inferences can be drawn against such suspects where they fail to answer any question 'material to the investigation of the offence' during the pre-trial period. This is defined very broadly to include any question requesting the defendant to give a full account of his movements, actions, activities or associations during any specific period as well as questions relating to evidence that the accused may be directing a criminal organisation. As observed by the Irish Human Rights Commission, "[t]he definition of a "material question" ... could apply to a very broad range of questions that could arise during police questioning, if not potentially all questions'.60 Additionally, unlike the adverse inference provision in the 2007 Act, there is no

58 DPP v Healy [1990] 2 IR 73; Lavery v Member in Charge, Carrickmacross Garda Station, unreported, 23 February 1999, SC.

59 To use Tribe's term. See L. Tribe, 'Trial by Mathematics: Precision and Ritual in the Legal Process' (1971) 84(6) Harv LR 1329 at 1370.

60 Irish Human Rights Commission, Observations on the Scheme of the Criminal Justice (Amendment) Bill 2009 (Irish Human Rights Commission: Dublin, 2009) (own emphasis). 
provision that the circumstances at the time clearly called for an explanation from the accused.

\section{(b) Exceptions to the presumption}

As in England and Wales, statutory exceptions to the presumption in the form of reverse-onus provisions are occurring with increasing frequency. Campbell et al. ${ }^{61}$ cite at least three significant statutory presumptions and reverse-onus clauses enacted in the last 10 years or so relating to liabilities of company law officers under the Companies Acts, possession of drugs and duties under health and safety legislation. Further, these provisions join a long list of statutory exceptions in the terrorist realm of the type at issue in cases such as O'Leary and Hardy (considered below). Part of the problem, it is submitted, stems from the overly deferential approach taken by the judiciary to legislative encroachments such that 'scant, almost dismissive, attention ${ }^{62}$ is afforded the arguments of those pleading unconstitutionality. The poverty of the judicial approach in this area is perhaps most evident in the case law formerly developed by the Supreme Court on historic sex abuse cases which will be examined presently, but it is intended to discuss at this juncture the case law on the constitutionality of statutory provisions placing an onus on the accused.

The first of these cases, O'Leary v $A G,{ }^{63}$ turned on the interpretation of s. 24 of the Offences Against the State Act 1939 which provides that possession or proof of possession by an accused of certain 'incriminating documents' shall be 'evidence, without more, until the contrary is proved' that the accused was a member of an unlawful organisation. Costello J in the High Court concluded that s. 24 only imposed an evidential burden of proof on the defendant, not a legal burden. Thus, the defendant could elect not to call evidence in the case and would still be entitled to an acquittal if the evidence did not establish his guilt beyond a reasonable doubt. His decision was upheld on appeal to the Supreme Court. O'Flaherty J held that the effect of the section was to amount to evidence only, the value of which could be shaken by cross-examination, or by pointing to the mental capacity of the accused or circumstances by which he came to be in possession of the document.

The second decision on statutory presumptions and the presumption of innocence was Hardy v Ireland ${ }^{64}$ which this time related to s. 4 of the Explosive Substances Act 1883. The section provides that it is an offence for any person who makes or has

61 Campbell, Kilcommins and O'Sullivan, above n. 21.

62 Ibid. at 349.

63 [1993] 1 IR 102, HC, [1995] 1 IR 254, SC.

64 [1994] 2 IR 55.

THE INTERNATIONAL JOURNAL OF EVIDENCE \& PROOF 
knowingly in his possession or under his control any explosive substance under such circumstances as to give rise to a reasonable suspicion that he is not making it or does not have it in his possession or under his control for a lawful object, unless he can show that he made it or had it in his possession or under his control for a lawful object. A majority of the Supreme Court (Hederman J, O'Flaherty and Blayney JJ concurring) held that the section merely placed an evidential burden on the accused and therefore did not violate the presumption. The minority, on the other hand, acknowledged that the legal burden had moved, but did not proffer persuasive argument as to why this did not meet with constitutional difficulties. Murphy J simply opined:

I do not see that there is any inconsistency between a trial in due course of law as provided for in Article 38.1 of the Constitution and a statutory provision ... which affords to an accused a particular defence of which he can avail if, but only if, he proves the material facts on the balance of probabilities.

The other member of the minority, Egan J, appeared to base his decision on the fact that the defence was created by statute and operated in a 'saving or excusatory' context. The reasoning of the majority of the Supreme Court in finding that the section moved only an evidential burden onto the accused is, with respect, spurious. As McGrath ${ }^{65}$ has argued: "[h]aving regard to the drafting of s.4(1) and in particular the use of the word "show" which equates to "prove" or "establish", it would appear that the conclusion of the minority that the section placed a legal burden on an accused was correct'.

It is possible to view the above decisions in two lights. First, one could argue that the Supreme Court, in much the same manner as the English courts (see below), has 'read down' the impugned sections in such a manner as to maximise the protection provided to the presumption of innocence. This does not appear to be the case, however, as there was no acknowledgement in either of the cases that the statutory provision did in fact reverse the probative burden (a truer reading of the section in Hardy, it is submitted). Moreover, a less benign view of the judgments laments the complete lack of guidance in an area impacting directly on the parameters of a cornerstone principle of the criminal law. In relation to these decisions Ní Raifeartaigh ${ }^{66}$ has remarked:

65 D. McGrath, Evidence (Thomson Round Hall: Dublin, 2005) 25.

66 U. Ní Raifeartaigh, 'Reversing the Burden of Proof in a Criminal Trial: Canadian and Irish Perspectives on the Presumption of Innocence' (1995) 5 ICLJ 135 at 153. 
[T] he presumption of innocence and its ramifications are barely touched on; ... No indication is given of whether there are limits to statutory restrictions of the presumption of innocence or what these limits might be; indeed, the approach of the majority almost appears to envisage that statute may restrict the presumption at will. If so, it is difficult to see any difference between the Irish position and that in England, where there is no constitutional guarantee of the presumption of innocence.

The judgments beg the question as to what test is to be applied in determining the constitutionality of future statutory incursions on the presumption. Certainly, if one takes the minority judgments in Hardy as a guide the dicta appear sufficiently broad to permit of a statutory reversal of the burden of proof in respect of criminal defences such as self-defence, provocation and intoxication. Moreover, a coda may be added to Ní Raifeartaigh's argument. English law has moved on since the publication of her article with the incorporation of the European Convention on Human Rights and a number of challenges to various statutory provisions. In two important cases the House of Lords has used its interpretive power under the Human Rights Act 1998 to convert many persuasive or legal burdens into mere evidential burdens. ${ }^{67}$ While different views continue to be taken of different statutory provisions, ${ }^{68}$ a number of principles can be derived from the case law, namely, that a statute may place a legal or evidential onus on the defence depending on the gravity of the conduct, the seriousness of the offence, the precise justification for placing the burden on the accused, and the degree of difficulty that the accused may have in discharging that burden. ${ }^{69}$ In Ireland, Hardy is authority for the proposition that reversals of the evidential and, potentially, legal burden of proof (and therefore prima facie breaches of the presumption of innocence) are constitutionally permissible, but little else. Given the existence in English law of criteria which can be said to afford some protection to the accused, at least in relation to more serious criminal offences, it would appear that, paradoxically, the 'golden thread' in Ireland enjoys a level of protection not dissimilar to that which it is afforded in a jurisdiction where it is without constitutional imprimatur.

67 R v Director of Public Prosecutions, ex p. Kebilene [2000] 2 AC 346; R v Lambert [2002] 2 AC 545.

68 As Ashworth, above n. 1 observes, there are a number of decisions which appear to prioritise public safety over the presumption of innocence. See, e.g., $R$ v Johnstone [2003] 1 WLR 1736; Sheldrake v Director of Public Prosecutions [2005] 1 AC 264.

69 R v Lambert [2002] 2 AC 545. Murphy notes that, despite differing decisions by the House of Lords on the legal and evidential burden, these principles have been applied fairly consistently: P. Murphy, Murphy on Evidence (Oxford University Press: Oxford, 2007) 94. 
While the above threat to the presumption (constituted by an absence of protective principles) cannot be minimised, by far the most significant development in this area in Ireland in recent years derives from a line of jurisprudence developed in the context of several historic sexual abuse cases where the presumption has been reversed. As Campbell et al. rightly observe this jurisprudence represented a serious challenge to the 'normative legitimacy' of the principle. ${ }^{70}$ In Ireland, an accused person who faces charges relating to a delayed complaint can make a judicial review application for an order of prohibition in a civil court on the grounds that the delay prejudices his or her right to a fair trial. In these applications in prosecutions for sexual abuse the presumption of innocence is called into question when the review court is required to consider the reasons advanced for the long periods of delay by complainants in revealing and reporting these offences. This delay by the complainant may of course be justifiable on the basis that it may often be attributable to the defendant either directly through threats or inducements to keep the abuse a secret or indirectly through the psychological effects of the abuse. The difficulty with this analysis, however, is that it is premised upon an assumption of guilt of the accused which would appear to violate the presumption of innocence enjoyed by the accused in relation to the charge(s).

A line of authority developed by the Irish Supreme Court-formulated in the decisions of $P C \mathrm{v} D P P,{ }^{71} \mathrm{JO}^{\prime} \mathrm{C} \mathrm{v} D P P^{72}$ and $P O^{\prime} \mathrm{C} \mathrm{v} D P P^{73}$-mandated a temporary assumption of guilt in relation to the charge of sexual abuse when the review court is considering the reasons advanced for the long periods of delay by complainants in revealing and reporting these offences. The former Supreme Court outlined a three-prong test when considering whether an order prohibiting the trial should be made. The first question concerned whether the delay is so long that the trial should be prohibited on account of the delay alone in the absence of specific prejudice. This requirement was rarely, if ever, satisfied. The second question required an assessment of the reasons for the delay and at this stage the defendant was to be presumed guilty of the offences, allowing an inquiry into whether 'the delay in making [the complaint] was referable to the accused's own actions'. The justification advanced by the former Chief Justice for infringing the presumption of innocence in this way was that of necessity. Keane CJ argued that:

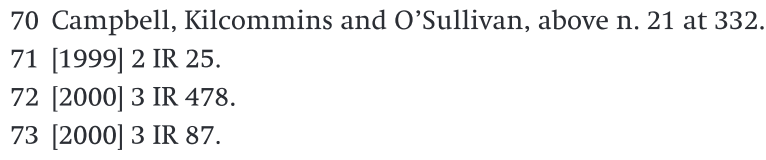


Without such an assumption, it would not be possible for the court to conduct any such inquiry and the court would be obliged automatically to halt the trial of a person because of the expiry of a lengthy period of time, even though the failure to make the complaint was due to domination exercised by the adult. ${ }^{74}$

At the third stage of the test the usual protections applied in determining whether the delay has prejudiced the defence to such an extent that there is a real and serious risk of an unfair trial.

As pointed out by members of the minority in $\mathrm{JO}^{\prime} \mathrm{C}$ and $\mathrm{PO}^{\prime} \mathrm{C}$, these decisions-in turning the presumption on its head-represented an unacceptable interference with the rights of the accused. Hardiman J (in JO'C) opined: 'there is in my view no basis whatever for assuming the truth of the allegations against the defendant, prior to conviction, for any purpose or in any proceedings' ${ }^{75}$ Similarly, Murray J in $P O^{\prime} \mathrm{C}$ held that an assumption of guilt, however contingent, is 'inconsistent with the fundamental rights of a citizen' ${ }^{76}$ For both judges the only relevant inquiry in such cases was whether the accused ran a real and serious risk of an unfair trial.

In fairness to the former Supreme Court, it should be noted that they viewed this abrogation of the presumption as highly exceptional, applying only to injunctive proceedings relating to delayed sexual abuse cases. There was no question but that the presumption would reapply at the trial for the offence(s) should the case proceed, a point which the court was at pains to emphasise. In the course of his judgment in $J O^{\prime} C$, Keane $C J$ held: ' $[t]$ he court must proceed on the assumption that the allegations are well founded and, to that extent only and solely in the context of these specific proceedings, the presumption of innocence does not apply. ${ }^{77}$ References were also made by the court in the later case of $\mathrm{PO}^{\circ} \mathrm{C}$ to the 'special nature of the offences' in question. In $J O^{\prime} C$, Hardiman $\mathrm{J}$ sought to reinforce the point that the decisions should not be taken as restricting the general scope of the presumption. Responding to arguments advanced by counsel that the presumption is an evidential rule applicable only at trial, he contends: 'Only the judgment of Lynch J. [in $P C$ ] appears at page 77, expressly to limit the presumption of innocence to the trial of the criminal proceedings' ${ }^{78}$ Yet the fact that efforts were made to limit the reversal of the presumption of innocence to a discrete process and area of law does not provide an answer to the argument that due process protections were being

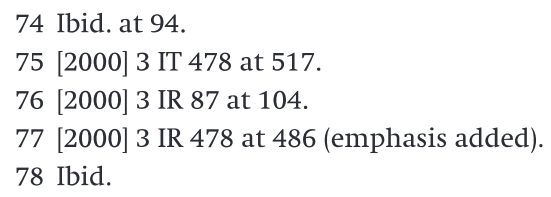


denied to the very defendants who needed them most. Sexual offenders generally and particularly child sex abusers are, as Fennell ${ }^{79}$ notes, society's current 'folk devils'. Society is understandably uncomfortable with such persons, but it is precisely at this juncture that the rules of evidence and due process guarantees are 'necessary to counterbalance our prejudices as fact-finders' ${ }^{80}$ Further, it is questionable whether this area of the law can be so conveniently and hermetically sealed. Fennell evokes the following colourful simile for such judicial tinkering:

[Such judicial modifications are like] individual body parts waiting to be transplanted. Independently each appears normal, but when combined they create a horrible Frankensteinian creature. The resulting body of law does not at all resemble anything remotely similar to traditional notions of fairness. ${ }^{81}$

In any event, in a reconstituted Supreme Court (Murray CJ presiding) the law has been restated and the presumption reasserted. In the decision of $S H \mathrm{v} D P P^{82}$ the Supreme Court moved away from the issue of culpability of the accused in explaining the delay to focus on the overriding issue of the accused's right to a fair trial. The test as currently formulated asks:

... whether there is a real or serious risk that the applicant, by reason of the delay, would not obtain a fair trial, or that a trial would be unfair as a consequence of the delay. The test is to be applied in light of the circumstances of the case ... Any question of an assumption, which arose solely for the purpose of applications of this nature, of the truth of the complainants' complaints against an applicant no longer arises. ${ }^{83}$

We turn now to the final, and perhaps less overt, threat to the presumption to be examined in an Irish context, namely the circumvention of the presumption through the introduction of civil orders to fulfil penal aims.

79 C. Fennell, 'The Culture of Decision Making: A Case for Judicial Defiance through Evidence and Fact-finding' (2001) 2(1) JSIJ 25.

80 Ibid. at 65 .

81 Ibid. at 35, quoting W. Patton, 'Evolution in Child Abuse Litigation: The Theoretical Void Where Evidentiary and Procedural Worlds Collide' (1992) 25(3) Loyola of Los Angeles Law Review 1009.

82 [2006] 3 IR 575.

83 Ibid. at 620 


\section{(c) Evasion: recourse to the civil law}

The contemporary preoccupation with risk and the reorientation of the criminal justice system towards the control of offenders thought to pose particular risks to social order and security is seen by Ashworth as productive of effects inimical to the presumption of innocence. It has been noted elsewhere that Ireland has remained relatively immune to risk analysis in its penal discourse and practice at least in its narrow computational sense. ${ }^{84}$ Certainly, Ireland has not witnessed the proliferation of civil orders which have been introduced in recent years in the United Kingdom such as football banning orders, violent offender orders, etc. To some degree, however, the state's preoccupation with certain risk groups is evident through the introduction of anti-social behaviour orders and the introduction in 2001 of sex offender orders. ${ }^{85}$

The Criminal Justice Act 2006 made provision for 'civil orders' similar to the English ASBO, but with a slightly narrower definition. Anti-social behaviour capable of triggering an order is defined in s. 113(2) as:

[behaviour] in a manner that caused or, in all the circumstances, was likely to cause to one or more persons not of the same household-

(a) harassment,

(b) significant or persistent alarm, distress, fear or intimidation,

(c) significant or persistent impairment of their use or enjoyment of their property.

As discussed at the beginning of this article, hard questions must be asked concerning whether the procedure is being used as a means of subverting the strictures of the criminal law, including the presumption of innocence. Irish defendants without the benefit of the presumption in civil order proceedings can face penalties of up to six months' imprisonment for breach of the order. Section 115(9) of the 2006 Act states clearly that the standard of proof required is the civil standard of the balance of probabilities. In relation to the cognate issue of the admissibility of hearsay evidence the Act is silent; however, given that the proceedings are civil in nature, it would appear that hearsay evidence may be admitted to the extent that it is permitted in civil proceedings and, in practice, the rule is applied with less vigour in civil rather than criminal matters. McCann may

84 Kilcommins et al. write: 'it could not be said that risk analysis, in its narrow computational sense, is coming to dominate penal discourse or practice in Ireland' (see S. Kilcommins, I. O'Donnell, E. O'Sullivan and B. Vaughan, Crime, Punishment and the Search for Order in Ireland (IPA: Dublin, 2004) 256).

85 Sex Offenders Act 2001, Part 3.

THE INTERNATIONAL JOURNAL OF EVIDENCE \& PROOF 
certainly prove persuasive authority for the Irish courts should issues arise in relation to the compatibility of the legislation with Article 6 of the European Convention on Human Rights, subject, of course, to a ruling by the European Court of Human Rights on the issue. ${ }^{86}$ On the other hand, s. 115(9) is difficult to reconcile with the dicta of their Lordships in McCann as to the standard of proof.

A related matter is the constitutionality of the legislation in the light of Article 38.1 (the right to a trial in due course of law) which enshrines the presumption of innocence for persons charged with a criminal offence. Should the courts find that the relevant provisions of the 2006 Act were in reality criminal and the necessary safeguards had therefore been avoided, they would be struck down as unconstitutional. Key to such a determination is the issue of whether the courts will consider the initial application for an ASBO as capable of separation from the later proceedings for breach. Despite the conclusion reached by the House of Lords in McCann, there are compelling reasons for finding that they are inextricably linked: the initial hearing defines the scope of the order and therefore determines the extent of the defendant's criminal liability; indeed, it is impossible to defend proceedings for breach without harking back to the terms of the original order. As argued by Binchy: ${ }^{87}$

... this rigorous segregation between the two stages of the ASBO process is less than convincing. There is an integration between each stage: the civil element is a necessary precondition of the criminal element: it defines the outer limits-and indeed may well define the full scope-of the conduct that can constitute a crime. There may turn out to be further interconnections, such as placing the onus on a defendant accused of breach to show that any breach was based on 'just cause or reasonable excuse'.

Another point, cogently made by McDonald, ${ }^{88}$ is that a person sentenced for breach of a civil order will in all likelihood be punished, not just for one act of defiance of the order, but for the previous anti-social acts committed by that person which led to the imposition of the order. It must be said, however, that cause for optimism that the courts will adopt an approach of 'substance over form' would not be derived from a brief survey of the Irish case law on the

86 The decision is under appeal to the European Court of Human Rights.

87 W. Binchy, 'Anti-Social Behaviour Orders and the Constitution', paper delivered at Conference on 'Anti-Social Behaviour Orders: Social Policy and Human Rights', Trinity College Dublin, 22 June 2005.

88 S. McDonald, 'The Nature of the Anti-Social Behaviour Order-R (McCann \& Others) v. Crown Court at Manchester' (2003) 66 MLR 630. 
characterisation of proceedings as civil or criminal. The High Court in Gilligan v Criminal Assets Bureau ${ }^{89}$ held that since the civil forfeiture procedure introduced under the Proceeds of Crime Act 1996 was labelled and operated as a civil process, it did not have 'all the features of a criminal prosecution'. This decision was followed by O'Higgins J in MF Murphy $\mathrm{v} \mathrm{GH}^{90}$ and both these decisions were upheld by the Supreme Court in a joint appeal. ${ }^{91}$ The crux of the Supreme Court's reasoning was that the indicia of criminal proceedings such as arrest, detention and admission to bail were not present. The narrow interpretation of 'criminal' adopted in these decisions, focusing on the labels and procedures of the procedure itself, is redolent of the House of Lords' approach in McCann, and would suggest that the hybrid structure of which ASBOs are comprised may well pass the constitutional litmus test.

\section{Conclusion}

It may, not unreasonably, be expected that the presumption of innocence would be better protected in a jurisdiction such as Ireland where it is afforded constitutional standing. The reality is much more nuanced, however, with both positive and negative features. Certain of Ashworth's threats to the presumption are also discernible in Ireland, particularly with regard to incentives to plead guilty, legislative curtailment of the right to silence and the growing legislative tendency of imposing burdens on the defence. In other respects the approach of the two jurisdictions to the presumption differs considerably. In terms at least of the principles governing the validity of exceptions to the presumption, the much more structured approach taken by the English courts means that a comparison with recent English jurisprudence is unfavourable. This divergence is perhaps surprising given the recent incorporation of the European Convention on Human Rights in both jurisdictions. While it may be expected that the Irish case law will evolve as further challenges are brought under Article 6(2) of the Convention, this may be some distance away given the conservative, even defensive approach taken by the Supreme Court to the Convention in the case of $M c D v ~ L .{ }^{92}$ It is to be hoped that in the near future a full consideration of the ramifications of reverse-onus provisions, particularly those governing the drugs and terrorism areas, will eventually be undertaken in Ireland in light of the important normative principles inherent in the presumption. This task assumes particular urgency given the short-lived, yet egregious, reversal of the presumption in a series of historic sexual abuse cases since the mid-1990s.

89 [1998] 3 IR 185.

90 Unreported, 4 June 1999, HC, O’Higgins J.

91 Murphy v GM, PB, PC Ltd, GH; Gilligan v Criminal Assets Bureau [2001] 4 IR 113.

92 [2009] IESC 81.

THE INTERNATIONAL JOURNAL OF EVIDENCE \& PROOF 
There are, however, other regards in which a cleaner bill of health may be given for the presumption in Irish law. While the entrenchment in Irish law of preventive civil orders represents a clear attempt at a deliberate blurring of the lines between civil and criminal process, there is an important gap here between the law in books and in practice. Only six civil orders have been issued since the legislation was introduced and there are also serious questions about the degree to which sex offenders are actively monitored by the Gardaí. ${ }^{93}$ This failure of implementation combined with the lesser enthusiasm shown by the Irish government for the introduction of hybrid orders effectively evading the presumption renders this threat to the presumption in Ireland less urgent than that posed by the other categories. Finally, one may note with some sense of satisfaction the recent decision by the Irish government not to pursue a constitutional amendment facilitating the introduction of absolute/strict liability offences. The strong objection taken to the criminalisation of the 'morally innocent' by commentators opposed to the amendment speaks to the continued potency of liberal constitutionalism and a paradigm of criminal law with the presumption of innocence at its core.

93 TV3 Nightly News with Vincent Brown, TV3, 14 January 2008. 